\title{
The influence of melatonin supplementation against aluminum-induced toxicity in brains of male rats
}

\author{
Ömür KARABULUT BULAN 1 (D), Bertan Boran BAYRAK $2 *$ (D) , Güner SARIKAYA-ÜNAL ${ }^{1}$ (D), \\ Refiye YANARDAĞ 2 (D) \\ 1 Department of Biology, Faculty of Science, İstanbul University-Cerrahpaşa, İstanbul, Turkey. \\ 2 Department of Chemistry, Faculty of Engineering, İstanbul University, Avcılar 34320 İstanbul, Turkey. \\ * Corresponding Author. E-mail: bertanb@istanbul.edu.tr (B.B.B.); Tel. +90-212-473 70 70/17672.
}

Received: 20 September 2018 / Revised: 01 November 2018 / Accepted: 03 November 2018

\begin{abstract}
Aluminum (Al), an ubiquitous element in nature, enters the body primarily through gastrointestinal tract, respiratory system and skin. Being a powerful neurotoxin for human brain, Al was reported to be involved in the etiology of Alzheimer's disease due to its easy access and accumulation in the central nervous system. Melatonin (Mel) is a tryptophan-derived neurohormone in animals and plants, and produced in the pineal gland of all mammalian species. The present study examines the effects of Mel on Al-induced oxidative stress, inflammation, tissue factor production and brain damage in rat brain. Wistar albino rats were divided into four groups. Group I: control animals; Group II: rats injected with $10 \mathrm{mg} / \mathrm{kg}$ Mel; Group III: rats injected with $5 \mathrm{mg} / \mathrm{kg} \mathrm{Al}\left(\mathrm{SO}_{4}\right)_{3}$; and Group IV: rats injected combination of $\mathrm{Al}$ and $\mathrm{Mel}\left(5 \mathrm{mg} / \mathrm{kg} \mathrm{Al}{ }_{2}\left(\mathrm{SO}_{4}\right)_{3}\right.$ and $\left.10 \mathrm{mg} / \mathrm{kg} \mathrm{Mel}\right)$. Animals were injected three times a week for one month. At the end of the month, rats were sacrificed, their brains were removed. It was found that lipid peroxidation, protein carbonyl, advanced oxidation protein products, hydroxyproline levels, tissue factor, catalase, superoxide dismutase, glutathione peroxidase, glutathione reductase, myeloperoxidase, acetylcholine esterase, alkaline phosphatase, acid phosphatase and glucose-6-phosphate dehydrogenase activities were increased, while paraoxonase, arylesterase, sodium potassium ATPase activities and glutathione levels were decreased in the Al-treated group. Mel treatment reversed these changes by demonstrating significant antioxidant effects. Results indicated that Mel has potential therapeutic value against Al-induced oxidative stress in the rat brain tissue and these effects may be related to its antioxidant activities.
\end{abstract}

KEYWORDS: Aluminum; melatonin; brain; oxidative stress; tissue factor levels.

\section{INTRODUCTION}

Metals are essential for biological organisms. In brain, metal ion homeostasis is necessary for normal brain functions and its arrangement has been considered as one of the key factors in the progression of neurodegeneration [1]. Brain tissue is susceptible to oxidative stress, thus, indefensible to damages induced by various chemicals and metals.

Aluminum (Al) is a highly reactive element. $\mathrm{Al}$ can mainly be found in kitchenware such as foils, in medicine and pharmaceuticals such as antacids, in cosmetic materials such as deodorants, in foods and food additives such as tea, herbs, cheese, corn and spices [2]. Furthermore, this metal is widely used in homes, hospitals, schools, commercial and office buildings, packaging, construction, containers, electrical conductors and other equipment. $\mathrm{Al}$ and its salts are widely used for the treatment and purification of drinking water [3]. This element has been associated with various diseases [4] and implicated in acceleration of brain aging. Al has a fixed oxidation number and a strong pro-oxidant activity despite its non-redox status [5]. Researchers searched for a link between oxidative stress and $\mathrm{Al}$ accumulation in different tissues and organs such as bone, spleen, kidney and brain [6-8]. Brain is the most susceptible organ for $\mathrm{Al}$ absorption and toxicity [9]. $\mathrm{Al}$ passes through the blood-brain barrier and is stored in the brain's cortex, cingulate bundles, corpus callosum, hippocampus and cerebellum $[10,11]$ that subsequently affecting the physiology and function of all regions of the brain [12].

How to cite this article: Karabulut-Bulan Ö, Bayrak BB, Sarıkaya-Ünal G, Yanardağ R. The influence of melatonin supplementation against aluminum-induced toxicity in brains of male rats. J Res Pharm. 2019; 23 (2): 275-283. 
Melatonin (Mel: N-acetyl-5-methoxytryptamine) is an indolamine, mainly synthesized by the pineal gland and many other organs during the night. Mel directly detoxifies various reactive oxygen (ROS) and nitrogen species (RNS) [13]. Thus, it plays an important role in scavenging free radicals and stimulates antioxidant system enzymes [14,15]. Several studies reported that Mel protects DNA, lipids, and proteins against the harmful effects of free radicals [16]. We aimed to investigate the effects of Mel in protection from Al-induced neural damage.

\section{RESULTS}

In Al-treated rats, reduced glutathione (GSH) levels were significantly less than the control group ( $p<$ 0.05). Administration of Mel to the $\mathrm{Al}$ in combination group resulted in an insignificant increase in GSH. Lipid peroxidation (LPO) levels in the brain tissues insignificantly increased in Al group. Protein carbonyl (PC), advanced oxidized protein products (AOPP) levels and tissue factor (TF) activity were remarkably raised in the $\mathrm{Al}$ group $(p<0.05 ; p<0.0001$, respectively). LPO, PC, AOPP levels and TF activity were reversed by the administration Mel $(p<0.05 ; p<0.0001$, respectively) (Table 1).

Table 1. Brain tissue GSH, LPO, PC, AOPP levels and TF activities for all groups.

\begin{tabular}{|c|c|c|c|c|c|}
\hline Group & $\begin{array}{c}\text { GSH } \\
\text { (nmol GSH/mg } \\
{\text { prot })^{\mathrm{a}}}\end{array}$ & $\begin{array}{c}\text { LPO } \\
\text { (nmol MDA/mg } \\
\text { prot) })^{a}\end{array}$ & $\begin{array}{c}\text { PC } \\
\text { (nmol/mg } \\
{\text { prot })^{\mathrm{a}}}^{-}\end{array}$ & $\begin{array}{c}\text { AOPP } \\
\text { (pmol/mg } \\
\text { prot) })^{\mathrm{a}}\end{array}$ & $\begin{array}{c}\text { TF } \\
(\mathrm{sec})^{a}\end{array}$ \\
\hline Control & $28.91 \pm 10.11$ & $2.44 \pm 0.97$ & $3.16 \pm 0.73$ & $1.97 \pm 0.59$ & $100.75 \pm 10.97$ \\
\hline $\begin{array}{l}\text { Control + } \\
\text { Melatonin }\end{array}$ & $26.17 \pm 5.59$ & $1.30 \pm 0.43$ & $2.46 \pm 1.13$ & $2.14 \pm 0.70$ & $119.17 \pm 7.05$ \\
\hline Aluminum & $10.42 \pm 4.71^{b}$ & $3.52 \pm 1.71$ & $8.42 \pm 4.56^{b}$ & $11.59 \pm 3.21^{b}$ & $67.44 \pm 7.97 \mathrm{~d}$ \\
\hline $\begin{array}{l}\text { Aluminum } \\
+ \text { Melatonin }\end{array}$ & $13.88 \pm 0.20$ & $0.93 \pm 0.61 c$ & $3.98 \pm 1.54^{c}$ & $2.08 \pm 0.62 c$ & $126.00 \pm 5.59 e$ \\
\hline
\end{tabular}

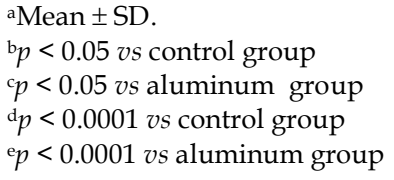

There was a significant increase in catalase (CAT), superoxide dismutase (SOD), glutathione peroxidase (GPx), glutathione reductase (GR), and myeloperoxidase (MPO) activities of the brain in Al group $(p<0.0001$; $p<0.005$, respectively) (Table 2). Mel caused a remarkable decrease in brain's CAT, SOD, GPx, GR and MPO activities in Al group ( $p<0.005 ; p<0.0001 ; p<0.05$, respectively) (Table 2).

Table 2. Brain tissue CAT, SOD, GPx, GR and MPO activities for all groups.

\begin{tabular}{lccccc}
\hline Group & $\begin{array}{c}\text { CAT } \\
\text { (U/mg prot) }^{\mathbf{a}}\end{array}$ & $\begin{array}{c}\text { SOD } \\
\text { (U/g prot) }^{\mathrm{a}}\end{array}$ & $\begin{array}{c}\text { GPx } \\
\text { (U/g prot) }^{\mathrm{a}}\end{array}$ & $\begin{array}{c}\text { GR } \\
\text { (U/g prot) }^{\mathbf{a}}\end{array}$ & $\begin{array}{c}\text { MPO } \\
\text { (mU/g tissue) }^{\mathbf{a}}\end{array}$ \\
\hline Control & $3.94 \pm 0.64$ & $6.50 \pm 1.54$ & $41.93 \pm 6.44$ & $29.24 \pm 5.50$ & $5.59 \pm 0.99$ \\
$\begin{array}{l}\text { Control + } \\
\text { Melatonin }\end{array}$ & $4.67 \pm 0.87$ & $7.94 \pm 2.80$ & $61.30 \pm 7.38$ & $19.83 \pm 12.57$ & $5.49 \pm 0.81$ \\
$\begin{array}{l}\text { Aluminum } \\
\begin{array}{l}\text { Aluminum }+ \\
\text { Melatonin }\end{array}\end{array}$ & $11.06 \pm 2.14^{\mathrm{b}}$ & $17.86 \pm 4.69 \mathrm{~b}$ & $113.91 \pm 24.11^{\mathrm{b}}$ & $37.57 \pm 2.08^{\mathrm{e}}$ & $16.91 \pm 3.58^{\mathrm{e}}$ \\
\hline
\end{tabular}

aMean \pm SD.

${ }^{\mathrm{b}} p<0.0001$ vs control group

$c_{p}<0.005$ vs aluminum group

$\mathrm{d} p<0.0001$ vs aluminum group

е $p<0.005$ vs control group

f $p<0.05$ vs aluminum group 
Xanthine oxidase $(\mathrm{XO})$ and acetylcholine esterase (AChE) activities in the brain were significantly increased in the $\mathrm{Al}$ group $(p<0.005, p<0.001$, respectively). Mel supplementation to $\mathrm{Al}$ group reversed this effect in $\mathrm{XO}$ and $\mathrm{AChE}$ activities ( $p<0.005 ; p<0.001$, respectively). On the other hand, paraoxonase (PON), aryl esterase (ARE) and sodium potassium ATPase $\left(\mathrm{Na}^{+} / \mathrm{K}^{+}\right.$-ATPase) activities in Al group were found to be notably decreased in comparison to those in the control rats ( $p<0.005 ; p<0.05 ; p<0.001$, respectively). However, Mel administration to the $\mathrm{Al}$ group caused a significant increase in the brain's PON, ARE and $\mathrm{Na}^{+} / \mathrm{K}^{+}$-ATPase activities $(p<0.05 ; p<0.0001$, respectively) (Table 3 ).

Table 3. Brain tissue $\mathrm{XO}, \mathrm{PON}, \mathrm{ARE}, \mathrm{AChE}$ and $\mathrm{Na}^{+} / \mathrm{K}^{+}-\mathrm{ATPase}$ activities for all groups.

\begin{tabular}{|c|c|c|c|c|c|}
\hline Group & $\begin{array}{c}\mathrm{XO} \\
(\mathrm{U} / \mathrm{g} \text { prot)a } \\
\end{array}$ & $\begin{array}{c}\text { PON } \\
\text { (U/g prot)a }\end{array}$ & $\begin{array}{c}\text { ARE } \\
\text { (U/g prot)a } \\
\end{array}$ & $\begin{array}{c}\text { AChE } \\
(\mathrm{U} / \mathrm{mg} \text { prot })^{\mathrm{a}}\end{array}$ & $\begin{array}{c}\mathrm{Na}^{+} / \mathrm{K}^{+}-\mathrm{ATPase} \\
\text { (nmol } P_{i} / \mathrm{mg} \text { prot/h)a }\end{array}$ \\
\hline Control & $1.22 \pm 0.28$ & $11.02 \pm 3.76$ & $196.85 \pm 29.90$ & $0.83 \pm 0.07$ & $3.42 \pm 1.32$ \\
\hline $\begin{array}{l}\text { Control + } \\
\text { Melatonin }\end{array}$ & $0.92 \pm 0.43$ & $6.98 \pm 2.58$ & $165.50 \pm 47.12$ & $0.83 \pm 0.10$ & $6.46 \pm 2.87$ \\
\hline Aluminum & $3.18 \pm 0.94 b$ & $4.71 \pm 0.95^{b}$ & $123.20 \pm 30.01 \mathrm{e}$ & $1.41 \pm 0.23^{f}$ & $1.21 \pm 0.55^{f}$ \\
\hline $\begin{array}{l}\text { Aluminum } \\
+ \text { Melatonin }\end{array}$ & $1.07 \pm 0.19 c$ & $6.44 \pm 0.85 \mathrm{~d}$ & $165.87 \pm 7.18^{d}$ & $0.88 \pm 0.11 \mathrm{~g}$ & $3.95 \pm 0.85 \mathrm{~h}$ \\
\hline
\end{tabular}

\footnotetext{
aMean \pm SD.

${ }^{\mathrm{b}} p<0.005$ vs control group

$c p<0.005$ vs aluminum group

$\mathrm{d} p<0.05$ vs aluminum group

e $p<0.05$ vs control group

${ }^{\mathrm{f}} p<0.001$ vs control group

sp $<0.001$ vs aluminum group

${ }^{\mathrm{h}} p<0.0001$ vs aluminum group
}

There was a significant increase in alkaline phosphatase (ALP) and acid phosphatase (ACP) and glucose-6-phosphate dehydrogenase (G6PD) activities in the brain tissues in Al group $(p<0.0001 ; p<0.05$, respectively) (Table 4). However, Mel treatment reversed this effect, resulting in notable decreases in ALP, ACP and G6PD activities ( $p<0.0001 ; p<0.05 ; p<0.001$, respectively). Hydroxyl proline (OH-proline) contents were significantly higher in $\mathrm{Al}$ group than those in the control group $(p<0.0001)$. Nevertheless, Mel was capable of reversing this change in Al group $(p<0.0001)$ (Table 4).

Table 4. Brain tissue ALP, ACP and G6PD activities and $\mathrm{OH}$-proline levels for all groups.

\begin{tabular}{|c|c|c|c|c|}
\hline Group & $\begin{array}{c}\text { ALP } \\
\text { (U/g prot)a }\end{array}$ & $\begin{array}{c}\text { ACP } \\
\text { (U/g prot)a }\end{array}$ & $\begin{array}{c}\text { G6PD } \\
\text { (U/g prot)a }\end{array}$ & $\begin{array}{l}\text { OH-proline } \\
\text { ( } \mu \mathrm{g} / \mathrm{mg} \text { prot) }\end{array}$ \\
\hline Control & $8.06 \pm 0.87$ & $14.80 \pm 2.75$ & $20.58 \pm 4.99$ & $52.81 \pm 11.96$ \\
\hline $\begin{array}{l}\text { Control + } \\
\text { Melatonin }\end{array}$ & $7.53 \pm 1.12$ & $15.02 \pm 1.99$ & $23.14 \pm 6.41$ & $41.05 \pm 6.66$ \\
\hline Aluminum & $15.92 \pm 1.18^{b}$ & $23.29 \pm 6.10^{d}$ & $43.76 \pm 10.04^{b}$ & $82.46 \pm 6.35^{b}$ \\
\hline $\begin{array}{l}\text { Aluminum + } \\
\text { Melatonin }\end{array}$ & $7.10 \pm 1.53 c$ & $17.88 \pm 2.37 \mathrm{e}$ & $23.27 \pm 8.13^{f}$ & $57.30 \pm 5.49 c$ \\
\hline
\end{tabular}

aMean \pm SD.

${ }^{\mathrm{b}} p<0.0001$ vs control group

$c p<0.0001$ vs aluminum group

$\mathrm{d}_{p}<0.05$ vs control group

e $p<0.05$ vs aluminum group

f $p<0.001$ s aluminum group 


\section{DISCUSSION}

Metals are needed for majority of enzymatic activities, mitochondrial function and myelination as well as neurotransmission. Toxic metals pose a global health risk because of their potential to contribute to a variety of diseases. $\mathrm{Al}$ is considered toxic to the central nervous, skeletal and hematopoietic systems. Al can cross the blood-brain barrier and cannot be eliminated from the brain. Brain, which is highly susceptible to oxidative stress, is vulnerable to damages induced by several chemical products, including metals [17]. High levels of ROS cause injuries by means of oxidative modifications of proteins, lipids and nucleic acid and neurons [18]. ROS was previously shown to cause apoptosis, inflammation and cell proliferation in various tissues.

Depletion of GSH, an important antioxidant in the brain, has been implicated in several neurodegenerative disorders [19]. In this study, GSH levels in rat brain were decreased under metal-induced stress. Decrease in GSH levels could be due to an increase in oxidative stress and exhaustion of GSH stores. However, Mel reversed GSH levels by exhibiting antioxidant effects in Al combination group.

Neuronal tissue MDA levels were assayed as an indicator of membrane oxidative damage. MDA levels increased in a way that suggests free radical attack on membrane lipids. Al caused notable oxidative damage by increasing the redox-active iron concentration in the brain [20]. In this study, the significant increase in the LPO levels in brain suggests that free radical-induced oxidative cell damage could mediate the toxicity of Al. Mel reduced the LPO levels in the brain. The oxidative damage in the brain was repaired in Al combination group following the administration of Mel.

$\mathrm{Al}$ administrations also caused a notable increase in PC and AOPP levels which are the markers of protein oxidation, and thus, an indicator of oxidative stress [21]. Oxidative modification of proteins leads to reduced specific protein function [22]. Oxidative modification of proteins may affect a variety of cellular functional proteins such as receptors, transport systems, enzymes as well as the signal transduction [23]. In the current study, PC and AOPP levels were increased in the Al group. These findings were consistent with results from other studies [24,25]. Application of Mel to the Al combination group reversed PC and AOPP levels. These results indicated that Mel could be effective in preventing oxidative protein damage.

Some organs, such as brain, lungs, heart, testes and skin and body fluids exhibit high TF activity [26,27]. As the clotting time is inversely proportional to the TF activity, the lengthening of clotting time is a manifestation of decreased TF activity [28]. Increased TF activity in many tissues is related to extensive cellular damage. In the current study, TF activity was significantly increased in rats administered Al. Increased TF activity showed that $\mathrm{Al}$ treatment could play a role in development of inflammation due to oxidative injury. Mel reversed this activity exhibiting notable antioxidant activity in the Al group. Decreased TF activity of the brain may have importance in terms of reducing the risk of thrombosis. It can be postulated that this reversal might be correlated to protection of membrane stability by Mel [29].

Increased antioxidant enzyme activity in the brain tissues of Al-treated rats appears to be a reaction to increased ROS generation [30]. These antioxidant enzymes may be alleviating the toxic effects of ROS. In our study, Al treatment caused a significant increase in the CAT, SOD, GPx and GR activities. Increased production of free radicals may subsequently increase the SOD activity resulting in production of higher amounts of $\mathrm{H}_{2} \mathrm{O}_{2}$. In organism, CAT activity increases in response to high $\mathrm{H}_{2} \mathrm{O}_{2}$ production. CAT detoxifies peroxides that are formed [31]. Similar results were reported by Gómez et al. [32]. Mel has been shown to stabilize mitochondrial functions and thus, will decrease the formation of ROS. Therefore, this study demonstrated the antioxidant properties of Mel in restoring the oxidative balance in the cell. GR catalyzes conversion of oxidized glutathione to its reduced form, by utilizing NADPH. In the present study, following the Al treatment, GR activity increased in the brain tissue. Mel returned GR to normal levels by demonstrating antioxidant effects in the Al group.

Neuroinflammation is an important contributor in the pathogenesis of neurodegenerative diseases [33]. $\mathrm{MPO}$ is an enzyme necessary for normal neutrophil function. This is released as a response to various stimulatory substances. Al exacerbates oxidative damage in brain that causes inflammation [34]. Increased MPO activity shows that Al-induced brain injury is a neutrophil-dependent inflammatory condition. Neutrophils play a role in oxidative damage via mechanisms that involve the activation of MPO enzyme systems. This enzyme activity increases due to oxidative stress. It has been shown that the MPO is enhanced in rats given $\mathrm{Al}$ by various researchers [35,36]. Our results demonstrated that in $\mathrm{Al}$ combination group toxicity, administration of Mel inhibited neutrophil infiltration and balanced oxidant-antioxidant levels in the brain tissue. It may be stated that Mel treatment could be used in individuals who are at risk of Al toxicity.

Increased $\mathrm{XO}$ activity may cause further tissue damage due to free radical generation. In this study, brain $\mathrm{XO}$ activity increased in the experimental group. Moumen et al. [37] showed that $\mathrm{Al}$ increased the XO 
activity in the brain tissue. Here, administration of Mel decreased XO activity, therefore, it can be suggested that Mel reduces oxidative stress. In a previous report regarding the ability of Mel to decrease XO activity in the brain, it was demonstrated that antioxidant properties of Mel are mainly related to the decrease of the prooxidant enzyme activities such as $\mathrm{XO}$ [38].

PON received significant attention due to its possible relationship with neurodegenerative disease $[39,40]$. These results proposed that enzyme was inactivated by increased oxidative stress and/or direct inhibition by Al. PON1 is an antioxidant and antiaterogenic enzyme [41]. PON1 protects the nervous system against toxicity. Hernández et al. [42] investigated whether environmental exposure to metals has any influence on PON1 activity or not. In the present study PON and ARE activities were reduced significantly in the brains of rats injected with Al. This might be due to the inactivation of the enzyme by Al. Administration of Mel could reverse PON and ARE activities in $\mathrm{Al}$ combination group.

$\mathrm{AChE}$ is an important regulatory enzyme. This enzyme is found in the brain, muscles, erythrocytes and cholinergic neurons [43] and this enzyme hydrolyzes the neurotransmitter acetylcholine. AChE activity was shown to increase in Al-treated rat brain [44-46]. This increase may be due to a direct neurotoxic effect exhibited via LPO of the plasma membrane, and such changes in plasma membranes may affect the integrity and functionality of the cholinergic system. Increases in AChE activity caused by Al treatment may lead to a reduction of cholinergic neurotransmission due to a decrease in acetylcholine levels in the synaptic cleft. In our study, AChE activity decreased significantly after treatment with Mel. This decrease might improve cholinergic neurotransmission by restoring acetylcholine levels.

$\mathrm{Na}^{+} / \mathrm{K}^{+}-\mathrm{ATPase}$ is very susceptible to structural changes in membrane [47]. Al administration increased LPO levels and, in return, LPO products inhibited integrated ion transport proteins. In several studies inhibitory effect of $\mathrm{Al}$ on $\mathrm{Na}^{+} / \mathrm{K}^{+}$-ATPase was observed in brain tissue [48,49]. A decrease in $\mathrm{Na}^{+} / \mathrm{K}^{+}$-ATPase activity can indicate membrane injury. In the present study, it was also observed that $\mathrm{Al}$ inhibited $\mathrm{Na}^{+} / \mathrm{K}^{+}$ ATPase. Failure of $\mathrm{Na}^{+} / \mathrm{K}^{+}$-ATPase has been implicated in the pathology of neurodegenerative diseases. Yu [50] showed the critical role of $\mathrm{Na}^{+} / \mathrm{K}^{+}$-ATPase in signal transduction and cell death pathways (apoptosis, necrosis and hybrid cell death). Here, Mel treatment significantly increased $\mathrm{Na}^{+} / \mathrm{K}^{+}$-ATPase activities in the brain. Mel might have prevented the inhibition of $\mathrm{Na}^{+} / \mathrm{K}^{+}$-ATPase activity by means of detoxification of ROS.

Increases or decreases in ALP activity are observed in a variety of pathologic processes [51]. ALP activity has been shown to alter inflammatory processes and tissue damage by Oktay et al. [52]. There was a significant increase in ALP activity in the Al group. Mel treatment decreased ALP activity in Al combination group. Increased ALP activity is an indication of inflammation and neutrophil activation caused by $\mathrm{Al}$ in the brain. Akinrinade et al. [53] and Sumathi et al. [49] also found increased ALP activity in rat brain after treatment with Al. Similarly, the present study showed that Al treatment led to significant elevation of ACP activity in brain. Increased ACP activity may result in phosphate accumulation within the lysosomes and an increase in catabolic rate. Mel treatment caused marked reduction in the ALP and ACP activities in Al combination group.

G6PD, an enzyme of the pentose phosphate shunt, produces the reducing NADPH for GSH generation [54]. This enzyme activity is increased in the brain of experimental animals treated with Al [55,56]. Increased G6PD activity indicates oxidation of glucose through the hexose monophosphate pathway, thereby facilitating increased production of NADPH for detoxification process. This, in return, leads to increased enzyme activities as a response to elevated brain peroxide metabolism. In the present study, Al significantly increased G6PD activity in the brain. Mel significantly decreased the G6PD activity in the Al combination group. The results suggested that Mel enhances pentose phosphate shunt pathway, generating a larger number of reduced NADP molecules for detoxification.

It was determined that the $\mathrm{OH}$-proline levels in brain were increased in Alzheimer's disease (AD) patients [57]. In the present study, brain $\mathrm{OH}$-proline levels were increased in Al-treated group. $\mathrm{OH}$-proline levels in the brain change as a consequence of the brain injury caused by Al. Here, Mel decreased the $\mathrm{OH}$ proline levels in brain. It shows that the decrease of OH-proline levels prevented brain damage.

\section{CONCLUSION}

$\mathrm{Al}$ has adverse effects on human health. Its introduction could generate free radicals, resulting in elevation of neural LPO, PC, AOPP, TF and OH-proline levels and changes in enzymatic and nonenzymatic antioxidant levels. According to the results of our study, Mel may have significant protective effects against Al induced oxidative brain damage by inhibiting free radical production, supporting antioxidant redox system. Mel scavenges oxygen based reactants, stabilizes the mitochondrial membrane. Mel administration can be an effective treatment to alleviate the damage that $\mathrm{Al}$ produces. 
In conclusion, Mel treatment modulates the antioxidant redox system and reduces brain oxidative stress induced by Al. For this reason, Mel may be a useful agent for the treatment neurodegenerative diseases such as $\mathrm{AD}$.

\section{MATERIALS AND METHODS}

\subsection{Animals}

All experimental protocols were approved by the Animal Care and Use Committee of Istanbul University (Ethical Committee: 102/27.08.2009). Male Wistar albino rats, weighing 230-250 g were obtained from The Animal Laboratory of Institute of Experimental Medicine. The animals fed with a standard pellet and access to water was allowed ad libitum.

\subsection{Experimental design}

The animals were separated into four groups. Each group was consisted of 8 rats. Group I: control animals were injected intraperitoneally (i.p.) with physiological saline; group II: animals were injected subcutaneously (s.c.) with $10 \mathrm{mg} / \mathrm{kg}$ Mel; group III: animals were injected (i.p.) with $5 \mathrm{mg} / \mathrm{kg} \mathrm{Al} \mathrm{Al}_{2}\left(\mathrm{SO}_{4}\right)_{3}$; Group IV: animals were injected combination of $\mathrm{Al}$ and Mel. Animals were injected three times a week for 1 month. Mel was dissolved in a small amount of ethanol and diluted with physiological saline. In the last day of experimental period, rats were sacrificed by ketamine hydrochloride and the brain tissues were removed.

\subsection{Biochemical assays}

Brain tissue samples were homogenized in $0.9 \% \mathrm{NaCl}$ solution. The clear supernatant was removed while the pellet was discarded and used for carrying out the total protein, GSH, LPO, PC, OH-proline and AOPP levels, TF activity, enzyme analysis.

Reduced GSH and malondialdehyde (MDA, LPO marker) levels in brain homogenates were determined according to Beutler [58] and Ledwożyw et al. [59], respectively. PC and AOPP levels were assayed according to Levine et al. [60] and Witko-Sarsat et al. [61] methods, respectively. The Quick's method [28] was used for performing TF activity measurements in the brain tissue homogenates. Protein estimation was conducted by using Lowry method [62].

CAT activity was carried out in the brain tissue by the method described by Aebi [63]. SOD, GPx, GR, $\mathrm{MPO}, \mathrm{XO}, \mathrm{PON}, \mathrm{ARE}, \mathrm{AChE}, \mathrm{Na}^{+} / \mathrm{K}^{+}$-ATPase, ALP and ACP and G6PD activities and OH-proline levels were determined by spectrophotometric methods, respectively [64-75].

\subsection{Statistical analysis}

Biochemical results were evaluated using an unpaired $t$-test and ANOVA variance analysis using the NCSS statistical computer package. The values were expressed as mean \pm SD. The value of $p<0.05$ was regarded as significant.

Acknowledgement: Authors are thankful to Istanbul University, for providing assistance from Scientific Research Project Coordination Unit (Project number BEK-2016-22789) to carry out the present work.

Author contributions: Concept - O.K.B., B.B.B., G.S.U., R.Y; Design - O.K.B., B.B.B., R.Y.; Supervision - O.K.B., B.B.B., G.S.U., R.Y; Materials - O.K.B., B.B.B., G.S.U., R.Y; Data Collection and/or Processing - O.K.B., B.B.B., R.Y; Analysis and/or Interpretation -B.B.B., R.Y.; Literature Search - O.K.B., B.B.B., R.Y.; Writing - O.K.B., B.B.B., R.Y.; Critical Reviews - O.K.B., B.B.B., G.S.U., R.Y.

Conflict of interest statement: The authors declared no conflict of interest.

\section{REFERENCES}

[1] Nelson N. Metal ion transporters and homeostasis. EMBO J. 1999; 18(16): 4361-4371. [CrossRef]

[2] Verstraeten SV, Aimo L, Oteiza PI. Aluminium and lead: molecular mechanisms of brain toxicity. Arch Toxicol. 2008; 82(11): 789-802.

[3] Bhattacharjee S, Zhao Y, Hill JM, Culicchia F, Kruck TP, Percy ME, Pogue AI, Walton JR, Lukiw WJ. Selective accumulation of aluminum in cerebral arteries in Alzheimer's disease (AD). J Inorg Biochem. 2013; 126: 35-37. [CrossRef] 
[4] Fulgenzi A, Vietti D, Ferrero ME. Aluminium involvement in neurotoxicity. BioMed Res Int. 2014; 2014. [CrossRef]

[5] Zatta P, Ibn-Lkhayat-Idrissi M, Zambenedetti P, Kilyen M, Kiss T. In vivo and in vitro effects of aluminum on the activity of mouse brain acetylcholinesterase. Brain Res Bull. 2002; 59(1): 41-45. [CrossRef]

[6] Reinke CM, Breitkreutz J, Leuenberger H. Aluminium in over-the-counter drugs: risks outweigh benefits? Drug Saf. 2003; 26(14): 1011-1025.

[7] Şahin G, Varol I, Temizer A, Benli K, Demirdamar R, Duru S. Determination of aluminum levels in the kidney, liver, and brain of mice treated with aluminum hydroxide. Biol Trace Elem Res. 1994; 41(1-2): 129-135.

[8] Sushma NJ, Rao KJ. Total ATPases activity in different tissues of albino mice exposed to aluminium acetate. J Environ Biol. 2007; 28(2 Suppl): 483-484.

[9] Krewski D, Yokel RA, Nieboer E, Borchelt D, Cohen J, Harry J, Kacew S, Lindsay J, Mahfouz AM, Rondeau V. Human health risk assessment for aluminium, aluminium oxide, and aluminium hydroxide. J Toxicol Environ B. 2007; 10(1): $1-269$.

[10] Makala LH. The role of indoleamine 2, 3 dioxygenase in regulating host immunity to leishmania infection. J Biomed Sci. 2012; 19(5): 1-8.

[11] Yuan CY, Lee YJ, Hsu GSW. Aluminum overload increases oxidative stress in four functional brain areas of neonatal rats. J Biomed Sci. 2012; 19: 51.

[12] Yu L, Jiang R, Su Q, Yu H, Yang J. Hippocampal neuronal metal ion imbalance related oxidative stress in a rat model of chronic aluminum exposure and neuroprotection of meloxicam. Behav Brain Funct. 2014; 10(6): 1-10.

[13] Abdel Moneim AE, Ortiz F, Leonardo-Mendonca RC, Vergano-Villodres R, Guerrero-Martínez JA, López LC, AcuñaCastroviejo D, Escames G. Protective effects of melatonin against oxidative damage induced by Egyptian cobra (Naja haje) crude venom in rats. Acta Trop. 2015; 143: 58-65. [CrossRef]

[14] Reiter JR, Tan DX, Rosales-Corral S, C. Manchester L. The universal nature, unequal distribution and antioxidant functions of melatonin and its derivatives. Mini Rev Med Chem. 2013; 13(3): 373-384.

[15] Rodriguez C, Mayo JC, Sainz RM, Antolin I, Herrera F, Martin V, Reiter RJ. Regulation of antioxidant enzymes: a significant role for melatonin. J Pineal Res. 2004; 36(1): 1-9.

[16] Reiter RJ, Tan DX, Osuna C, Gitto E. Actions of melatonin in the reduction of oxidative stress. J Biomed Sci. 2000; 7(6): 444-458.

[17] Nazıroğlu M. Role of selenium on calcium signaling and oxidative stress-induced molecular pathways in epilepsy. Neurochem Res. 2009; 34(12): 2181-2191.

[18] Nazıroğlu M, Kutluhan S, Uğuz AC, Çelik Ö, Bal R, Butterworth PJ. Topiramate and vitamin E modulate the electroencephalographic records, brain microsomal and blood antioxidant redox system in pentylentetrazol-induced seizure of rats. J Membr Biol. 2009; 229(3): 131-140.

[19] Wang W, Ballatori N. Endogenous glutathione conjugates: occurrence and biological functions. Pharmacol Rev. 1998; 50(3): 335-356.

[20] Praticò D, Uryu K, Sung S, Tang S, Trojanowski JQ, Lee VM. Aluminum modulates brain amyloidosis through oxidative stress in APP transgenic mice. FASEB J. 2002; 16(9): 1138-1140.

[21] Butterfield DA, Lauderback CM. Lipid peroxidation and protein oxidation in Alzheimer's disease brain: potential causes and consequences involving amyloid $\beta$-peptide-associated free radical oxidative stress 1,2 . Free Radic Biol Med. 2002; 32(11): 1050-1060. [CrossRef]

[22] Stadtman ER. Protein oxidation and aging. Science. 1992; 257(5074): 1220-1224. [CrossRef]

[23] Evans P, Lyras L, Halliwell B. Measurement of protein carbonyls in human brain tissue. Methods Enzymol. 1999; 300: 145-156. [CrossRef]

[24] Al-Amin MM, Reza HM, Saadi HM, Mahmud W, Ibrahim AA, Alam MM, Alam MM, Kabir N, Saifullah ARM, Tropa ST, Quddus AHRM. Astaxanthin ameliorates aluminum chloride-induced spatial memory impairment and neuronal oxidative stress in mice. Eur J Pharmacol. 2016; 777: 60-69. [CrossRef]

[25] Sharma DR, Wani WY, Sunkaria A, Kandimalla RJ, Verma D, Cameotra SS, Gill KD. Quercetin protects against chronic aluminum-induced oxidative stress and ensuing biochemical, cholinergic, and neurobehavioral impairments in rats. Neurotox Res. 2013; 23(4): 336-357.

[26] Emekli-Alturfan E, Kasikci E, Yarat A. Tissue factor activities of streptozotocin induced diabetic rat tissues and the effect of peanut consumption. Diabetes Metab Res Rev. 2007; 23(8): 653-658. 
[27] Mackman N. Role of tissue factor in hemostasis, thrombosis, and vascular development. Arterioscler Thromb Vasc Biol. 2004; 24(6): 1015-1022.

[28] Ingram G, Hills M. Reference method for the one-stage prothrombin time test on human blood. International committee for standardization in hematology. Thromb Haemost 1976; 36(1): 237-238.

[29] García J, Reiter R, Pié J, Ortiz G, Cabrera J, Sáinz R, Acuña-Castroviejo D. Role of pinoline and melatonin in stabilizing hepatic microsomal membranes against oxidative stress. J Bioenerg Biomembr. 1999; 31(6): 609-616.

[30] Benzi G, Marzatico F, Pastoris O, Villa R. Relationship between aging, drug treatment and the cerebral enzymatic antioxidant system. Exp Gerontol. 1989; 24(2): 137-148.

[31] Reddy PH. Amyloid precursor protein-mediated free radicals and oxidative damage: Implications for the development and progression of Alzheimer's disease. J Neurochem. 2006; 96(1): 1-13.

[32] Gómez M, Esparza JL, Nogués MR, Giralt M, Cabré M, Domingo JL. Pro-oxidant activity of aluminum in the rat hippocampus: gene expression of antioxidant enzymes after melatonin administration. Free Radic Biol Med. 2005; 38(1): 104-111.

[33] Frank-Cannon TC, Alto LT, McAlpine FE, Tansey MG. Does neuroinflammation fan the flame in neurodegenerative diseases? Mol Neurodegener. 2009; 4(1): 47.

[34] Nehru B, Bhalla P, Garg A. Further evidence of centrophenoxine mediated protection in aluminium exposed rats by biochemical and light microscopy analysis. Food Chem Toxicol. 2007; 45(12): 2499-505. [CrossRef]

[35] Bulan NÖ, Sarıkaya-Ünal G, Tunalı S, Arda-Pirinççi P, Yanardağ R. Melatonin is a potent modulator of antioxidative defense and cellular proliferation against aluminum toxicity in rats. Turk J Biol. 2015; 39(6): 911-924. [CrossRef]

[36] Kaur P, Sodhi R. Memory recuperative potential of rifampicin in aluminum chloride-induced dementia: Role of pregnane x receptors. Neuroscience. 2015; 288: 24-36. [CrossRef]

[37] Moumen R, Ait-Oukhatar N, Bureau F, Fleury C, Bouglé D, Arhan P, Neuville D, Viader F. Aluminium increases xanthine oxidase activity and disturbs antioxidant status in the rat. J Trace Elem Med Biol. 2001; 15(2): 89-93. [CrossRef]

[38] Teixeira A, Morfim MP, Cordova CA, Charão CC, Lima VR, Creczynski-Pasa TB. Melatonin protects against prooxidant enzymes and reduces lipid peroxidation in distinct membranes induced by the hydroxyl and ascorbyl radicals and by peroxynitrite. J Pineal Res. 2003; 35(4): 262-268.

[39] Abdel-Salam OM, Khadrawy YA, Mohammed NA. Neuroprotective effect of nitric oxide donor isosorbide-dinitrate against oxidative stress induced by ethidium bromide in rat brain. EXCLI J. 2012; 11: 125-141.

[40] Menini T, Gugliucci A. Paraoxonase 1 in neurological disorders. Redox Rep. 2014; 19(2): 49-58.

[41] Rajkovic MG, Rumora L, Barisic K. The Paraoxonase 1, 2 and 3 in humans. Biochem Med. 2011; 21(2): 122-130.

[42] Hernández AF, Gil F, Leno E, López O, Rodrigo L, Pla A. Interaction between human serum esterases and environmental metal compounds. Neurotoxicology. 2009; 30(4): 628-635. [CrossRef]

[43] Grisaru D, Sternfeld M, Eldor A, Glick D, Soreq H. Structural roles of acetylcholinesterase variants in biology and pathology. Eur J Biochem. 1999; 264(3): 672-686.

[44] Kumar A, Dogra S, Prakash A. Protective effect of curcumin (Curcuma longa), against aluminium toxicity: Possible behavioral and biochemical alterations in rats. Behav Brain Res. 2009; 205(2): 384-390. [CrossRef]

[45] Kumar A, Prakash A, Dogra S. Neuroprotective effect of carvedilol against aluminium induced toxicity: possible behavioral and biochemical alterations in rats. Pharmacol Rep. 2011; 63(4): 915-923. [CrossRef]

[46] Ravi S, Prabhu B, Raju T, Bindu P. Long-term effects of postnatal aluminium exposure on acetylcholinesterase activity and biogenic amine neurotransmitters in rat brain. Indian J Physiol Pharmacol. 2000; 44(4): 473-478.

[47] Rodrigo R, Rivera G, Orellana M, Araya J, Bosco C. Rat kidney antioxidant response to long-term exposure to flavonol rich red wine. Life Sci. 2002; 71(24): 2881-2895. [CrossRef]

[48] Silva VS, Duarte AI, Rego AC, Oliveira CR, Gonçalves PP. Effect of chronic exposure to aluminium on isoform expression and activity of rat $\left(\mathrm{Na}^{+} / \mathrm{K}^{+}\right)$ATPase. Toxicol Sci. 2005; 88(2): 485-494. [CrossRef]

[49] Sumathi T, Shobana C, Thangarajeswari M, Usha R. Protective effect of L-Theanine against aluminium induced neurotoxicity in cerebral cortex, hippocampus and cerebellum of rat brain-histopathological, and biochemical approach. Drug Chem Toxicol. 2015; 38(1): 22-31.

[50] Yu SP. $\mathrm{Na}^{+}, \mathrm{K}^{+}$-ATPase: The new face of an old player in pathogenesis and apoptotic/hybrid cell death. Biochem Pharmacol. 2003; 66(8): 1601-1609. [CrossRef] 
[51] Millán JL. Alkaline phosphatases: Structure, substrate specificity and functional relatedness to other members of a large superfamily of enzymes. Purinergic Signal. 2006; 2(2): 335-341.

[52] Oktay S, Alev B, Tunali S, Emekli-Alturfan E, Tunali-Akbay T, Koc-Ozturk L, Yanardag R, Yarat A. Edaravone ameliorates the adverse effects of valproic acid toxicity in small intestine. Human Exp Toxicol. 2015; 34(6): 654-661. [CrossRef]

[53] Akinrinade ID, Memudu AE, Ogundele OM. Fluoride and aluminium disturb neuronal morphology, transport functions, cholinesterase, lysosomal and cell cycle activities. Pathophysiology. 2015; 22(2): 105-115. [CrossRef]

[54] Chance B, Sies H, Boveris A. Hydroperoxide metabolism in mammalian organs. Physiol Rev. 1979; 59(3): 527-605.

[55] Martins RN, Harper CG, Stokes GB, Masters CL. Increased cerebral glucose-6-phosphate dehydrogenase activity in Alzheimer's disease may reflect oxidative stress. J Neurochem. 1986; 46(4): 1042-1045.

[56] Tiwari M. Glucose-6-phsphate dehydrogenase (G6PD) and neurodegenerative disorders: Mapping diagnostic and therapeutic opportunities. Genes Dis. 2018; 4(4): 196-203. [CrossRef]

[57] Kalaria RN, Pax AB. Increased collagen content of cerebral microvessels in Alzheimer's disease. Brain Res. 1995; 705(1): 349-352. [CrossRef]

[58] Beutler E, Red Cell Metabolism: A Manual of Biochemical Methods, second ed., Grune \& Stratton, New York, USA 1975.

[59] Ledwożyw A, Michalak J, Stępień A, Kądziołka A. The relationship between plasma triglycerides, cholesterol, total lipids and lipid peroxidation products during human atherosclerosis. Clin Chim Acta. 1986; 155(3): $275-283$.

[60] Levine RL, Garland D, Oliver CN, Amici A, Climent I, Lenz AG, Ahn BW, Shaltiel S, Stadtman ER. Determination of carbonyl content in oxidatively modified proteins. Methods Enzymol. 1990; 186: 464-478. [CrossRef]

[61] Witko-Sarsat V, Friedlander M, Capeillère-Blandin C, Nguyen-Khoa T, Nguyen AT, Zingraff J, Jungers P, DescampsLatscha B. Advanced oxidation protein products as a novel marker of oxidative stress in uremia. Kidney Int. 1996; 49(5): 1304-1313. [CrossRef]

[62] Lowry OH, Rosebrough NJ, Farr AL, Randall RJ. Protein measurement with the folin phenol reagent. J Biol Chem. 1951; 193(1): 265-275.

[63] Aebi H, Catalase in vitro. Methods Enzymol. 1984; 105: 121-126. [CrossRef]

[64] Mylroie AA, Collins H, Umbles C, Kyle J. Erythrocyte superoxide dismutase activity and other parameters of copper status in rats ingesting lead acetate. Toxicol Appl Pharmacol. 1986; 82(3): 512-520. [CrossRef]

[65] Wendel A. Glutathione peroxidase. Methods Enzymol. 1981; 77: 325-333. [CrossRef]

[66] Beutler E, Red Cell Metabolism: A Manual of Biochemical Methods. Grune \& Stratton, New York, USA 1971.

[67] Wei H, Frenkel K. In vivo formation of oxidized DNA bases in tumor promoter-treated mouse skin. Cancer Res. 1991; 51(16): 4443-4449.

[68] Corte ED, Stirpe F. Regulation of xanthine oxidase in rat liver: modifications of the enzyme activity of rat liver supernatant on storage at 20 degrees. Biochem J. 1968; 108(2): 349-351.

[69] Furlong CE, Richter R, Seidel S, Motulsky A. Role of genetic polymorphism of human plasma paraoxonase/arylesterase in hydrolysis of the insecticide metabolites chlorpyrifos oxon and paraoxon. Am J Hum Genet. 1988; 43(3): 230-238.

[70] Gan KN, Smolen A, Eckerson HW, La Du BN. Purification of human serum paraoxonase/arylesterase. Evidence for one esterase catalyzing both activities. Drug Metab Dispos. 1991; 19(1): 100-106.

[71] Ellman GL, Courtney KD, Andres V, Featherstone RM. A new and rapid colorimetric determination of acetylcholinesterase activity. Biochem Pharmacol. 1961; 7(2): 88-95.

[72] Ridderstap A, Bonting S. Na+-K+-activated ATPase and exocrine pancreatic secretion in vitro. Am J Physiol. 1969; 217(6): 1721-1727.

[73] Walter K, Schütt C. Alkaline phosphatase in serum (continuous assay). In: Bergmeyer HU. (Ed). Methods in Enzymatic Analysis, Academic Press, New York, USA, 1974; pp.860-864. [CrossRef]

[74] Beutler E, Red Cell Metabolism: A Manual of Biochemical Methods, third ed., Grune\& Stratton, New York, USA 1984.

[75] Reddy GK, Enwemeka CS. A simplified method for the analysis of hydroxyproline in biological tissues. Clin Biochem. 1996; 29(3): 225-229. [CrossRef] 